\title{
PREFERENSI WISATAWAN MILENIAL MANCANEGARA KE BADUNG, BALI
}

\author{
Ni Kadek Mia Ayu Saputri ${ }^{1}$, I Made Kusuma Negara ${ }^{2}$, I Wayan Suardana ${ }^{3}$ \\ ${ }^{1}$ Email : miaayusaputriipw14@gmail.com \\ Program Studi Industri Perjalanan Wisata, Fakultas Pariwisata, Universitas Udayana \\ ${ }^{2}$ Email : kusuma.negara@unud.ac.id \\ Program Studi Industri Perjalanan Wisata, Fakultas Pariwisata, Universitas Udayana \\ ${ }^{3}$ Email : suar.dana@yahoo.co.id \\ Program Studi Industri Perjalanan Wisata, Fakultas Pariwisata, Universitas Udayana
}

\begin{abstract}
In this era of tourism activities become a trend for the millennial generation. In tourism activities, of course, there are considerations in choosing an object as a destination for a tour or referred to as a reference. Tourist preferences need to be known to measure how much tourist interest in a tourist attraction. Badung, Bali is one of the biggest destinations for foreign tourists. The purpose of this study was to determine the characteristics, preferences, and attitudes of milenial tourists in choosing a tourist attraction in Badung. Data analysis techniqes used in this study is observation, questionnaire. Quantitative descriptive data analysis technique with the calculation of cross-tabulation and chi-square analysis and ideal point models. A total of 120 respondents were selected purposively, namely milenial foreign tourists aged 18--37 years. The characteristics of milenial tourists in this study the majority are aged 25--30 years, Country of origin Australia, last high school education, unmarried status, aiming for a vacation, staying 4--7 days, first visit, traveling with friends. The preferences of milenial tourists there are 9 preferences, among others, tourist activities where tourists choose to look around, on milenial tourists choose villas, where to eat millennial tourists choose restaurants, and on transportation, millennial tourists choose family cars. On Sosial Media used by tourists choosing Instagram, when using Sosial Media tourists choose 4--6 hours, when uploading photos of millennial tourists choose a few hours after editing photos, on information sites used by millennial tourists choose Google, and on photo capture tools that are used by millennial travelers to choose mobile phones. The attitude of millennial tourists in this study is that Badung has a tourist attraction that can be interpreted as good millennial tourist attitudes.
\end{abstract}

Abstrak : Pada era sekarang ini kegiatan wisata menjadi trend bagi generasi milenial. Dalam kegiatan wisata tentunya ada pertimbangan dalam memilih suatu obyek sebagai tempat tujuannya berwisata atau disebut dengan peferensi. Preferensi wisatawan perlu diketahui untuk mengukur seberapa besar minat wisatawan terhadap suatu daya tarik wisata. Badung, Bali adalah salah satu tujuan terbesar wisatawan mancanegara. Tujuan penelitian ini untuk mengetahui karakteristik, preferensi, serta sikap wisatawan milenial dalam memilih suatu daya tarik wisata di Badung. Teknik pengumpulan data yang digunakan pada penelitian ini yaitu observasi, kuesioner. Teknik analisis data deskriptif kuantitatif dengan perhitungan analisis tabulasi silang dan chi square serta ideal point model. Responden sejumlah 120 orang ditentukan secara purposive yaitu wisatawan milenial mancanegara berusia 18--37 tahun. Karakteristik dari wisatawan milenial pada penelitian ini mayoritas berusia 25--30 tahun, Negara asal Australia, pendidikan terakhir SMA, status belum menikah, bertujuan berlibur, lama tinggal 4--7 hari, kunjungan pertama kali, melakukan perjalanan dengan teman. Preferensi dari wisatawan milenial ada 9 preferensi antara lain Aktivitas wisatawan yang dimana wisatawan memilih melihat-lihat, pada akomodasi wisatawan milenial memilih villa, 
pada tempat makan wisatawan milenial memilih restaurant, dan pada transportasi wisatwan milenial memilih mobil keluarga. Pada media sosial yang digunakan wisatawan memilih instagram, pada waktu pengguanaan media sosial wisatawan memilih 4--6 jam, pada waktu upload foto wisatawan milenial memilih beberapa jam setelah mengedit foto, pada situs informasi yang digunakan wisatawan milenial memilih google, dan pada alat pengambilan foto yang digunakan wisatawan milenial memilih handphone. Sikap wisatawan milenial pada penelitian ini yaitu Badung memiliki daya tarik wisata yang dapat diinterprestasi sikap wisatawan milenial baik.

Keywords: attitudes, characteristics, millennial tourists, preferences.

\section{PENDAHULUAN}

Pariwisata menurut WTO (1999), adalah kegiatan manusia yang melakukan perjalanan ke dan tinggal di daerah tujuan di luar lingkungan kesehariannya. Gejala pariwisata telah ada semenjak adanya perjalanan manusia dari suatu temat ke tempat lain dan perkembangannya sesuai dengan sosial budaya masyarakat itu sendiri. Semenjak itu pula ada kebutuhna-kebutuhan manusia yang harus dipenuhi selama perjalanannya, disamping itu juga adanya motivasi yang mendorong manusia untuk memenuhi kebutuhan hidupnya. Seperti saat ini berwisata sudah menjadi sebuah kebutuhan dan gaya hidup seseorang. Trend gaya hidup berwisata ini semakin marak dengan didukung oleh informasi dari social media, reality show di televisi, dan artikel-artikel yang memuat tentang keberagaman pariwisata

Generasi Y dikenal dengan sebutan generasi millenial atau milenium. Ungkapan generasi Y mulai dipakai pada editorial koran besar Amerika Serikat pada Agustus 1993. Generasi ini banyak menggunakan teknologi komunikasi instan seperti email, SMS, instant messaging dan media sosial seperti facebook dan twitter, dengan kata lain generasi millenial adalah generasi yang tumbuh pada era internet booming (Lyons, 2004). Lebih lanjut (Lyons, 2004) mengungkapkan ciri - ciri dari generasi milllenial adalah: karakteristik masing-masing individu berbeda, tergantung dimana ia dibesarkan, strata ekonomi, dan sosial keluarganya, pola komunikasinya sangat terbuka dibanding generasi-generasi sebelumnya, pemakai media sosial yang fanatik dan kehidupannya sangat terpengaruh dengan perkembangan teknologi, lebih terbuka dengan pandangan politik dan ekonomi, sehingga mereka terlihat sangat reaktif terhadap perubahan lingkungan yang terjadi di sekelilingnya, memiliki perhatian yang lebih terhadap kekayaan.

Suatu sikap konsumen terhadap satu pilihan produk yang terbentuk melalui evaluasi atas berbagai macam merek dalam berbagai pilihan yang tersedia disebut preferensi konsumen (Kotler, 2009: 181). Preferensi Wisatawan adalah keinginan atau minat wisatawan terhadap suatu keadaan yang merupakan cerminan sikap kepribadian individu yang akan mengarahkan pada proses pencarian bentuk-bentuk kepuasan atau kesenangan yang spesifik. Preferensi wisatawan perlu diketahui untuk mengukur seberapa besar minat wisatawan terhadap suatu daya tarik wisata. Melihat hal tersebut penting untuk mengetahui preferensi atau pilihan daya tarik wisata yang disukai wisatawan milenial agar dapat manggaet pasar wisatawan milenial.

Salah satu daerah wisata yang terkenal di Indonesia akan daya tarik wisatanya adalah Pulau Bali. Bali yang dikenal akan objek wisatanya baik kekayaan alam maupun budayanya juga termasuk terpengaruh dengan perkembangan teknologi. Hotel-hotel di Bali juga melakukan promosi dan penjualan melalui internet, sehingga mudah dijangkau oleh semua kalangan terutama generasi milenial. Seperti yang dikemukakan (Lyons dalam Teori Perbedaan Generasi, Putra, 2016) mengenai generasi milenial yaitu memiliki karakter yang berbeda dari generasi sebelumnya, mereka adalah pemakai media sosial yang fanatic. Hal ini dibuktikan dengan banyaknya generasi milenial yang menggunakan internet di Indonesia. Generasi milenial dalam rentang usia 20--24 tahun dan 25--29 tahun memiliki angka penetrasi $80 \%$. Pada kategori 20--24 tahun ditemukan 22,3 juta jiwa yang setara $82 \%$ dari total penduduk dikelompok itu. Sedangkan pada kelompok 
25--29 tahun terdapat 24 juta pengguna internet atau setara $80 \%$ total jumlah jiwa. Media sosial merajai konten internet sebagai yang paling sering diakses netizen. Tercatat $97,4 \%$ orang Indonesia mengakses akun media sosial saat menggunakan internet. (www.cnnindonesia.com)

Kabupaten Badung mempunyai tempattempat yang sesuai dengan kebutuhan wisatawan milenial yang saat ini cenderung memilih tempat yang terkenal di media sosial. Berdasarkan data dari Badung dalam angka tahun 2016 dinyatakan bahwa Kabupaten Badung terdiri dari beberapa bagian daerah kecamatan, yaitu Kecamatan Kuta Selatan, Kecamatan Kuta, Kecamatan Kuta Utara, Kecamatan Mengwi, Kecamatan Abiansemal, dan Kecamatan Petang. Oleh karena itu lokasi penelitian yang akan digunakan dalam penelitian ini akan dibagi menjadi tiga klaster daerah yang dianggap banyak terdapat destinasi wisata dan banyak dikunjungi wisatawan berdasarkan daftar daya tarik wisata menurut lokasi di Kabupaten Badung Tahun 2018 (Badung Dalam Angka 2019), dimana klaster daerah tersebut adalah wilayah Petang, wilayah Kuta dan wilayah Kuta Selatan. Jadi beberapa daya tarik wisata yang berada di ketiga klaster daerah tersebut akan dijadikan sebagai lokasi penelitian yang dianggap sudah mewakili Kabupaten Badung untuk meneliti preferensi wisatawan milenial terhadap daya tarik wisata di Badung.

\section{METODE PENELITIAN}

Terdapat 3 variabel yaitu : Karakteristik, Preferensi, dan Sikap. Dengan definisi operasional untuk Karakteristik berdasarkan tourist descriptor yaitu jenis kelamin, usia, status perkawinan, tingkat pendidikan, pekerjaan, dan daerah asal. Berdasarkan trip descriptor yaitu tujuan perjalanan, lama perjalanan, waktu melakukan perjalanan, pengorganisasian perjalanan, teman perjalanan, periodic perjalanan, biaya selama di daya tarik wisata, pengeluaran biaya terbesar selama perjalanan, dan kunjungan kembali. Preferensi Wisatawan menggunakan 5 indikator yaitu jasa wisata, akomodasi, tempat makan dan minum, transportasi, dan aksesbilitas. Sikap Wisatawan diukur dengan 8 atribut yaitu daya tarik wisata, ketersediaan akomodasi, ketersediaan fasilitas utama dan pendukung, kualitas pelayanan destinasi wisata, aksesbilitas destinasi wisata, image destinasi wisata, tingkat harga destinasi wisata dan promosi destinasi wisata.

Teknik pengumpulan data yang digunakan yaitu observasi, kuesioner, dokumentasi, dan studi pustaka. Teknik penentun sampel adalah purposive sampling dengan ketentuan yang dijadikan responden wisatawan milenial mancanegara berusia 1837 tahun. Pada variabel sikap menggunakan teknik penentuan sampel tambahan yaitu cluster random sampling yang dimana peneliti meneliti 3 kecamatan dari 6 kecamatan yang ada di Kabupaten Badung sebagai lokasi penelitian secara acak karena setiap kecamatan tidak sama. Dengan jumlah 40 responden per kecamatan dikali 3 kecamatan yaitu 120 reponden.Teknik analisis data yang digunakan deskriptif kuantitatif dengan perhitungan analisis tabulasi silang dengan chi square menggunakan softwere SPSS. Sedangkan pada variable sikap dianalisis dengan ideal point model.

\section{HASIL DAN PEMBAHASAN}

Kabupaten Badung adalah salah satu daergah di Bali yang memiliki perkembangan wisata cukup pesat hal ini ditunjukkan berdasarkan data dari Dinas Pariwisata Kabupaten Badung mengenai Capaian kinerja pada indikator persentase daya tarik wisata yang memenuhi standar menunjukkan pada tahun 2018 sebesar 66\% (24 DTW) dari 36 daya tarik wisata yang ada di Kabupaten Badung. Dibandingkan dengan tahun 2017 sebesar 64\% (23 DTW). Capaian kinerja ini didukung oleh program pengembangan destinasi pariwisata dengan kegiatan pembangunan dan penataan DTW serta didukung oleh manajemen yang sudah tertata. Berdasarkan Peraturan Bupati Badung No.4 Tahun 2018 ada 3 DTW baru yang ditetapkan yaitu pantai Melasti, Pancoran Solas, dan Water Blow Peninsula Nusa Dua, sehingga DTW yang ada sebanyak 39 DTW. Jumlah kunjungan wisatawan mancanegara ke Kabupaten Badung 2018 mencapai 6.502.400 orang dengan rata-rata lama tinggal 4 hari. Pertumbuhan akomodasi pariwisata di Kabupaten Badung meningkat sebanyak 7\% dari tahun 2017 dengan total 1.744 akomodasi sedangkan pertumbuhan rumah makan, bar, dan restoran mencapai 2.042 pada tahun 2018. (Badung dalam angka 2019)

Karakteristik wisatawan milenial berdasarkan tourist descriptor di Kabupaten 
Badung, Bali berasal dari berbagai Negara dan yang mendominasi dari Australia. Wisatawan milenial yang mengisi kuesioner terdiri dari Kelompok usia wisatawan milenial berusia 25--30 tahun, dengan status belum menikah, dominan dari mereka masih menjadi mahasiswa dan pendidikan terkahir SMA. Sedangkan dilihat secara trip description atau gambaran mengenai perjalanannya, yaitu bahwa tujuan mereka datang ke Kabupaten Badung, Bali untuk liburan, mereka menghabiskan waktu liburannya selama 4--7 hari dan juga 8--14 hari, dengan berlibur di hari kerja karena dominan dari mereka berlibur karena baru menyelesaikan pendidikannya, dominan dari mereka pertama kali melakukuan kunjungan wisata ke Badung, Bali dengan mengatur perjalanannya sendiri dan pergi bersama temannya, selama berwisata di Badung, Bali pengeluaran harian terbesar mereka sebanyak Rp. 501.000--Rp. 1.000.000, dengan pengeluaran terbesar adalah tempat makan dan minum atau restaurant, dengan pengalaman mereka selama liburan di Badung, Bali mereka menyatakan bersedia untuk berlibur kembali.

Preferensi daya tarik wisata wisatawan millenial di Kabupaten Badung, Bali diklasifikasi menjadi lima preferensi, yaitu preferensi terhadap transportasi, akomodasi, tempat makanan dan minuman, aktivitas wisatawan, serta accesbility wisatawan millenial. Preferensi mayoritas wisatawan millenial dengan menggunakan transportasi mobil, akomodasi villa, jenis tempat makan dan minum restoran, aktivitas wisata sightseeing atau melihat-lihat, akun sosial media yang digunakan instagram, durasi penggunaan sosial media 4--6 jam perhari, situs yang digunkan untuk mencari informasi google, waktu menggunggah foto berlibur beberapa jam setelah mengedit foto, dan alat yang digunakan untuk mengambil foto adalah handphone.

Preferensi wisatawan yang memiliki hubungan dengan karakteristik tourist descriptor diantaranya pekerjaan yang berhubungan dengan durasi penggunaan media sosial, status perkawinan yang berhubungan dengan waktu mengunggah foto/video, negara asal dan usia yang berhubungan dengan situs yang digunakan dalam mencari daya tarik wisata, negara asal dan pekerjaan yang berhubungan dengan pemilihan tempat makan dan minum, negara asal berhubungan dengan aktivitas wisata, dan negara asal serta usia yang memiliki hubungan dengan media sosial.

Hal ini dikarenakan karakteristik wisatawan milenial yang berkunjung ke Kabupaten Badung memiliki tingkat kecenderungan yang berbeda tergantung dari negara asal, usia, pekerjaan dan status perkawinan wisatawan milenial yang berkunjung, sehingga dapat disimpulkan bahwa negara asal wisatawan lebih dominan menentukan preferensi yang dipilih saat berwisata ke Kabupaten Badung.

Preferensi wisatawan yang memiliki hubungan dengan karakteristik trip descriptor diantaranya tujuan berwisata, lama tinggal, pengorganisasian perjalanan, besar pengeluaran dan keperluan biaya yang berhubungan dengan pemilihan moda transportasi. Kemudian tujuan berwisata, lama tinggal, besar pengeluaran, keperluan biaya yang berhubungan dengan pemilihan aktivitas wisata. Selanjutnya lama tinggal dan jumlah kunjungan yang berhubungan dengan media sosial yang digunakan selama berwisata. Selanjutnya daya tarik wisata yang berhubungan dengan durasi penggunaan media sosial. Selanjutnya lama tinggal, jumlah kunjungan, dan besar pengeluaran memiliki hubungan dengan waktu mengunggah foto/video. Selanjutnya keperluan biaya yang berhubungan dengan situs yang digunakan dalam mencari daya tarik wisata di Kabupaten Badung, Terakhir jumlah kunjungan yang memiliki hubungan dengan media yang digunakan untuk berfoto oleh wisatawan milenial ketika berwisata di Kabupaten Badung.

Hal ini dikarenakan karakteristik wisatawan milenial yang berkunjung ke Kabupaten Badung memiliki tingkat kecenderungan yang berbeda tergantung dari tujuan berwisata, lama tinggal, pengorganisasian perjalanan, besar pengeluaran, keperluan biaya, jumlah kunjungan, dan pilihan daya tarik wisata, sehingga dapat disimpulkan bahwa lama tinggal wisatawan lebih dominan menentukan preferensi yang dipilih saat berwisata ke Kabupaten Badung.

Sikap wisatawan pada penelitian ini dianalisis dengan tiga tahap yaitu pertama menganalisis tingkat kepentingan atribut daya tarik wisata, yang kedua merekap kualitas masing-masing atribut daya tarik wisata ketiga menganalisis dengan ideal point model. 
Berdasarkan hasil analisis interpretasi sikap didapatkan bahwa para wisatawan milenial memiliki sikap yang berbeda-beda terhadap destinasi-destinasi wisata di Kabupaten Badung. Skor sikap terbaik atau peringkat pertama didapatkan oleh destinasi wisata kawasan Kuta dengan interpretasi sikap Baik, karena skor yang diperolehnya paling minimal dan mendekati nilai ideal yaitu sebesar 26,046 (nilai ideal terbaik adalah 0). Penilaian sikap yang positif dapat dilihat pada analisis kualitas atribut dimana kawasan Kuta memiliki nilainilai tertinggi di atribut tingkat harga destinasi wisata, aksesibilitas destinasi wisata, kualitas pelayanan destinasi wisata, promosi destinasi wisata, ketersediaan penginapan/hotel, ketersediaan fasilitas utama dan pendukung wisata, image destinasi wisata, dan daya tarik destinasi wisata. Destinasi wisata Bali hanya kalah dari Yogyakarta yang unggul di atribut tingkat harga.

Posisi kedua ditempati oleh kawasan Petang dengan interpretasi sikap Baik dan skor ideal point yang diperoleh sebesar 27,691 (mendekati nilai nol dan nilai ideal terbaik adalah 0). Peringkat kedua ini dikarenakan kawasan Petang merupakan kawasan yang masih asri dengan banyaknya daya tarik air terjun yang sangat terkenal. Posisi terakhir atau ketiga ditempati oleh kawasan Nusa Dua dengan interpretasi sikap Baik dan skor ideal point yang diperoleh sebesar 28,746 (mendekati nilai nol dan nilai ideal terbaik adalah 0).

Berdasarkan hasil observasi dilapangan harga yang dibayarkan oleh wisatawan milenial yang berkunjung ke kawasan Kuta, Nusa Dua untuk sighseeing tidak mengeluarkan biaya, sehingga wisatawan milenial yang berkunjung pertama kali dapat menikmati daya tarik wisata yang terdapat pada masing-masing daya tarik wisata. Sedangkan untuk harga yang dibayarkan untuk kawasan petang wisatawan milenial mancanegara hanya perlu mengeluarkan biaya sebesar Rp. 20.000,00 perorang.

\section{SIMPULAN}

Adapun preferensi daya tarik wisata wisatawan millenial di Kabupaten Badung, Bali diklasifikasi menjadi lima preferensi, yaitu preferensi terhadap transportasi, akomodasi, tempat makanan dan minuman, aktivitas wisatawan, serta accesbility wisatawan millenial. Preferensi mayoritas wisatawan millenial dengan menggunakan transportasi mobil, akomodasi villa, jenis tempat makan dan minum restoran, aktivitas wisata sightseeing atau melihat-lihat, akun sosial media yang digunakan instagram, durasi penggunaan sosial media 4--6 jam perhari, situs yang digunkan untuk mencari informasi google, waktu menggunggah foto berlibur beberapa jam setelah mengedit foto, dan alat yang digunakan untuk mengambil foto adalah handphone.

Selain itu, dapat disimpulakan bahwa hasil analisis tingkat kepentingan atribut ranking pertama atau yang dianggap paling penting oleh wisatawan milenial mancanegara untuk memutuskan kunjungan ke daya tarik wisata di Badung adalah tingkat harga destinasi wisata. Peringkat kedua ditempati oleh aksesibilitas destinasi wisata, peringkat ketiga kualitas pelayanan destinasi wisata, peringkat keempat ketersediaan penginapan/hotel, kelima ketersediaan fasilitas utama dan pendukung wisata, keenam daya tarik destinasi wisata, ketujuh promosi destinasi wisata, dan kedelapan ditempati oleh image destinasi wisata. Sedangkan destinasi wisata yang mendapatkan nilai-nilai tertinggi adalah kawasan Kuta. Atribut wisata di kawasan Kuta yang mendapat nilai tertinggi adalah tingkat harga destinasi wisata. Dari hasil perhitungan sikap dengan ideal point model maka dapat disimpulan bahwa Badung memiliki daya tarik wisata yang dapat diinterprestasi sikap wisatawan milenial baik. Dari ketiga daerah yaitu Kuta, Petang, dan Kuta Selatan memiliki interprestasi sikap yang sama baik, tetapi nilai yang paling unggul adalah Kuta. Kuta menjadi kawasan dengan peringkat tertinggi karena dibandingkan dua kawasan wisata lainnya Kuta merupakan kawasan dengan harga yang relatif dapat dijangkau oleh wisatawan. Penilaian sikap yang positif dapat dilihat pada analisis kualitas atribut dimana kawasan Kuta memiliki nilainilai tertinggi di atribut tingkat harga destinasi wisata, aksesibilitas destinasi wisata, kualitas pelayanan destinasi wisata, promosi destinasi wisata, ketersediaan penginapan/hotel, ketersediaan fasilitas utama dan pendukung wisata, image destinasi wisata, dan daya tarik destinasi wisata

\section{SARAN}

Sebaiknya pemerintah di Kabupaten Badung khususnya pada bidang pariwisata 
serta pengusaha jasa wisata di Badung lebih gencar melakukan promosi, karena dilihat dari negara asal yang berkunjung ke Badung masih didominasi dari satu negara. Maka destinasi wisata yang ada di Badung perlu di publikasikan pada media social yang sudah mudah dan banyak ada di era teknologi ini serta situs yang sering digunakan oleh wisatawan mencari informasi seputaran destinasi wisata.

Sebaiknya pemerintah setempat mengembangkan daya tarik wisata dengan memperhatikan fasilitas yang dibutuhkan wisatawan seperti tempat sampah, toilet dan fasilitas umum lainnya serta tempat yang nyaman dan bersih. Karena melihat trend saat ini wisatawan milenial banyak mengabadikan liburannya dengan berfoto pada daya tarik wisata sehingga tempat yang nyaman dan bersih membuat citra yang baik pada Badung. Sebaiknya pemerintah Kabupaten Badung serta pengelola daya tarik wisata di kawasan Nusa Dua dan Petang dapat mempertimbangkan untuk melakukan perbaikan atribut-atribut seperti harga, aksesbilitas dan kualitas pelayanan sehingga interprestasi sikap wisatawan milenial akan menjadi lebih baik. 


\section{Kepustakaan}

Cooper, dkk. 1995. Tourism, Principles and Prantice. London. Logman.

Demeter, Bratucu, Palade. 2015. Dynamics of the Youth Travel Market On A Global Level. Bulletin of the Transilvania University of Braşov Series V: Economic Sciences • Vol. 8 (57) No. 1 - 2015.

Dwiputra. 2013. Preferensi Wisatawan Terhadap Sarana Wisata di Kawasan Wisata Alam Erupsi Merapi. Jurnal Perencanaan Wilayah dan Kota, Vol. 24 No. 1. Badan Perencanaan dan Pembangunan Nasional.

Fernandez, Guzman Antonio Munoz. 2016. Youth and Tourism Perspective. Application to Hostels. Regional and Sectoral Economic Studies. Vol. 16-1.

Hair, J. F. 2006. Multivariate Data Analysis. Edisi 5. Jakarta: Gramedia Pustaka Utama.

Honeyball, Eleanor. 2017. Determining the Motivations of Milenial Travellers In the Context of Cultural Experiences In Southeast Asia. BA (Hons) International Tourism Management.

Kamus Besar Bahasa Indonesia. 2008. Edisi IV.

Kembaren. 2014. Preferensi Wisatawan Terhadap Kunjungan Wisata Pulau Samosir Dengan Analisis Konjoin. Vol. 02 No. 3. ISSN: 2337-9197. Saintia Matematika.

Kotler, Philip. 2009. Manajemen Pemasaran, Edisi 13. Jakarta: Erlangga
Kusmayadi. 2000. Metodologi Penelitian dalam Bidang Kepariwisataan. Jakarta: PT. Gramedia Pustaka Utama.

Manik, Gayatri. 2016. Faktor Pendorong Dan Penarik Wisatawan Backpacker Mancanegara Berwisata Ke Bali. Jurnal IPTA ISSN: 2338-8633 Vol. 4 No. 2.

Meilani, Yohana Cahya Palupi. 2016. Identifikasi Aspek Sumber Daya Manusia Pariwisata Subsektor Perhotelan Tanggerang Berdasarkan Persepsi Wisatawan Generasi Milenial. Conference on Management and Behavioral Studies.Universitas Taruma Negara, Jakarta.

Mowen dan Minor, 2012, Perilaku Konsumen Jilid 1, Edisi Kelima (terjemahan), Erlangga, Jakarta.

Nazir, Moh. 2005. Metode Penelitian. Jakarta: Ghalia Indonesia.

Nursusanti. 2005. Atraksi Wisata. Jakarta: Erlangga.

Pendit, I Noman S. 1994. Ilmu Pariwisata Sebuah Pengantar Perdana. Jakarta: Pradnya Paramita.

Pitana, I Gde dan Gayatri G Putu.2005. Sosiologi Pariwisata. Yogyakarta: C.V ANDI OFFSET

Putra, Yanuar Surya. 2016. Theoritical Review: Teori Perbedaan Generasi. Among Makarti Vol.9 No.18, Desember 2016. STIE AMA Salatiga.

Soekadijo, 2003. Anatami Pariwisata : Memahami Pariwisata Sebagai Systemic, Jakarta: PT Gramedia Pustaka Utama. 
Sugiarto, Endar dan Kusmayadi. 2000. Metode Penelitian dalam Bidang Kepariwisataan, Jakarta: PT Gramedia Pustaka Utama.

Sugiyono, 2007, Metode Penelitian Kuantitatif, Kualitatif, dan $R \& D$. Bandung: Alfabeta.

Sugiyono, 2013, Metode Penelitian Kuantitatif, Kualitatif, dan $R \& D$. Bandung: Alfabeta.

Sumarwan, Ujang. 2012. Riset Pemasaran dan Wisatawan. Bogor: IPB Press.

Suwena, I Ketut \& Widyatmaja, I Gst Ngr., 2010, Pengetahuan Dasar Ilmu Pariwisata. Udayana University Press: Denpasar.

World Tourism Organitation (WTO), 1999, International Tourismof a Global

Yoeti, Oka A. 1985. Budaya Tradisional yang Nyaris Punah. Jakarta: Departemen Pendidikan dan Kebudayaan.

Yoeti, Oka A. 1996. Pengantar Ilmu Pariwisata. Bandung: Angkasa.

Yusendra, Muhamad Ariza Eka. 2016. Pengukuran Sikap Domestik Terhadap Destinasi-Destinasi Wisata Indonesia Dengan Menggunakan Ideal Point Model. Jurnal Manajemen Magister. Vol. 02 No. 01.

Zanuar, Zyendira Amanda. 2017. Preferensi Wisatawan Berpasangan Mancanegara Terhadap Produk Wisata Di Gili Trawangan, Lombok Utara, Nusa Tenggara Barat. Jurnal IPTA. Vol. 5 No. 1. 